\title{
The evidence of indirect transmission of SARS-CoV-2 reported in Guangzhou, China
}

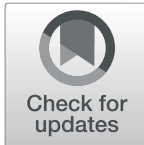

Chaojun Xie ${ }^{1,2+}$, Hongjun Zhao ${ }^{1,3 \dagger}$, Kuibiao Li ${ }^{1,2 \dagger}$, Zhoubin Zhang ${ }^{1,2+}$, Xiaoxiao Lu ${ }^{4}$, Huide Peng ${ }^{5}$, Dahu Wang ${ }^{1,2}$, Jin Chen ${ }^{5}$, Xiao Zhang ${ }^{1,2}$, Di Wu ${ }^{1,2}$, Yuzhou Gu $u^{1,2}$, Jun Yuan ${ }^{1,2}$, Lin Zhang ${ }^{1,2^{*}}$ and Jiachun $\mathrm{Lu}^{1,3^{*}}$ (D)

\begin{abstract}
Background: More than 2 months have passed since the novel coronavirus disease 2019 (COVID-19) first emerged in Wuhan, China. With the migration of people, the epidemic has rapidly spread within China and throughout the world. Due to the severity of the epidemic, undiscovered transmission of COVID-19 deserves further investigation. The aim of our study hypothesized possible modes of SARS-CoV-2 transmission and how the virus may have spread between two family clusters within a residential building in Guangzhou, China.

Methods: In a cross-sectional study, we monitored and traced confirmed patients and their close contacts from January 11 to February 5, 2020 in Guangzhou, China, including 2 family cluster cases and 61 residents within one residential building. The environmental samples of the building and the throat swabs from the patients and from their related individuals were collected for SARS-CoV-2 and tested with real-time reverse transcriptase polymerase chain reaction (RT-PCR). The relevant information was collected and reported using big data tools.

Results: There were two notable family cluster cases in Guangzhou, which included 3 confirmed patients (family No.1: patient $A, B, C$ ) and 2 confirmed patients (family No.2: patient D, E), respectively. None of patients had contact with other confirmed patients before the onset of symptoms, and only patient A and patient B made a short stop in Wuhan by train. Home environment inspection results showed that the door handle of family No.1 was positive of SARS-CoV-2. The close contacts of the 5 patients all tested negative of SARS-CoV-2 and in good health, and therefore were released after the official medical observation period of 14-days. Finally, according to the traceability investigation through applying big data analysis, we found an epidemiological association between family No.1 and family No.2, in which patient D (family No.2) was infected through touching an elevator button contaminated by snot with virus from patient A (family No.1) on the same day.

Conclusions: Contaminants with virus from confirmed patients can pollute the environment of public places, and the virus can survive on the surface of objects for a short period of time. Therefore, in addition to the conventional droplet transmission, there is also indirect contact transmission such as snot-oral transmission that plays a crucial role in community spread of the virus.
\end{abstract}

Keywords: Novel coronavirus disease, Severe acute respiratory syndrome coronavirus 2, Snot-oral transmission, Indirect transmission

\footnotetext{
* Correspondence: 378563318@qq.com; jclu@gzhmu.edu.cn

${ }^{\dagger}$ Chaojun Xie, Hongjun Zhao, Kuibiao Li and Zhoubin Zhang contributed

equally to this work.

${ }^{1}$ The Institute for Public Health, Guangzhou Medical University, 195

Dongfengxi Road, Guangzhou 510182, PR China

Full list of author information is available at the end of the article
}

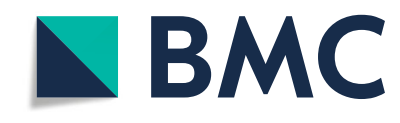

(c) The Author(s). 2020 Open Access This article is licensed under a Creative Commons Attribution 4.0 International License, which permits use, sharing, adaptation, distribution and reproduction in any medium or format, as long as you give appropriate credit to the original author(s) and the source, provide a link to the Creative Commons licence, and indicate if changes were made. The images or other third party material in this article are included in the article's Creative Commons licence, unless indicated otherwise in a credit line to the material. If material is not included in the article's Creative Commons licence and your intended use is not permitted by statutory regulation or exceeds the permitted use, you will need to obtain permission directly from the copyright holder. To view a copy of this licence, visit http://creativecommons.org/licenses/by/4.0/. The Creative Commons Public Domain Dedication waiver (http://creativecommons.org/publicdomain/zero/1.0/) applies to the data made available in this article, unless otherwise stated in a credit line to the data. 


\section{Background}

In late December 2019, an outbreak of the novel coronavirus disease 2019 (COVID-19) caused by the severe acute respiratory syndrome coronavirus 2 (SARS-CoV-2) was reported by the local health facilities in Wuhan, China [1, 2]. The epidemic has been spreading to many other Chinese cities [3-5]. As the spread escalated, the World Health Organization (WHO) declared that the SARS-CoV-2 outbreak constitutes a "Public Health Emergency of International Concern" on January 30, 2020, and the epidemic has escalated to a pandemic since March 11, 2020.

With the information from epidemiological investigation and clinical manifestation accumulating, evidence indicated that there existed person-to-person transmission of COVID-19 [6, 7]. In order to elucidate the reason for the rapid spread of the disease, the researchers examined whether the virus could survive in external environment and found detectable nucleic acid of SARS-CoV-2 in environmental sample gathered from South China Seafood Market in Wuhan, the place where the virus first broke out. Other studies also showed that the virus was also found in patients' feces and urine [8]. The preexisting evidence suggests that contaminants from patients can pollute the environment of public places and indirectly indicates the possibility of contact transmission. Due to the fact that the Chinese government had invested a lot of resources and adopted various measures to manage the impact of the outbreak, the number of confirmed COVID-19 cases and suspected cases has begun to decline slowly since 15 February 2020, and there has been no new cases for days in several provinces and cities [9]. But the epidemic has not completely come to an end and we still need to remain vigilant continuously especially because of the migration of large populations and the gradual reopening of public places. New reports have shown that the virus continues to spread, yet we still have very few understandings of the characteristics of the virus, and therefore need further investigation. As reported in this study, there were two interesting family cluster cases reported in Guangzhou, providing the evidence of snot-oral indirect transmission of SARS-CoV-2.

\section{Methods}

A cross-sectional study was conducted to investigate the possible modes of SARS-CoV-2 transmission between 2 family clusters within the same residential building in Guangzhou, China. Between January 11, 2020 and February 5,2020 , two family cluster cases included 5 confirmed patients reported in one residential building. We investigated cases, close contacts, the residents,security guards and janitors of this building. On January 30, we sampled aerosol and surface samples from the elevator and the houses of the two families. On February 1, we sampled blood samples and throat swabs from the residents of this building, and throat swabs collected from the security guards and janitors. On February 3, 2020, the second batch of surface samples from the elevator and the houses of the two families were collected. The environmental samples of the building and the throat swabs from the patients and their related individuals were tested with real-time reverse transcriptase polymerase chain reaction (RT-PCR) for SARS-CoV-2. The relevant information was collected and analyzed using big data tools.

\section{Data collection}

All information of traceability investigation was collected using big data tools and reported by Guangzhou Center for Disease Control and Prevention (Guangzhou CDC), and the field epidemiological investigations were conducted by the staff of Guangzhou municipal and Baiyun district centers for disease control and prevention based on the "questionnaire on individual case of COVID-19 cases" and the "questionnaire on Individual case of suspected COVID-19 cases". The pharyngeal swabs, blood samples, aerosol samples and surface samples were collected by medical staff in hospitals or during the field investigation, and safely sent to Guangzhou Centre for Disease Control and Prevention. The real-time reversetranscriptase-polymerase-chain-reaction (RT-PCR) assay was performed to confirm the infection caused by the SARS-Cov-2 virus. The informed consent was obtained from each participant and this epidemiological study was approved by the Ethical Committee of Guangzhou Centre for Disease Control and Prevention.

\section{Study definitions \\ Big data tools}

The "big data tools" is a database containing information about monitored and traced cases and close contacts accumulated and managed by Guangzhou CDC, from which we get the information of 2 family cluster cases and 61 residents of same residential building from January 11 to February 5, 2020 in Guangzhou, China.

\section{Sample collection}

3 aerosol samples and 21 surface samples were collected from the elevator and the houses of the two families. In addition to collecting throat swabs from 5 confirmed patients, there were 61 blood samples and 61 throat swabs collected from the residents of this building, and 14 throat swabs collected from security guards and janitors, as shown in Table 2.

\section{Viral nucleic acid test}

Laboratory confirmation of the SARS-CoV-2 by RT-PCR assay (Shanghai BioGerm Medical Biotechnology) was 
conducted in Guangzhou Center for Disease Prevention and Control (Guangzhou CDC). The RT-PCR assay was performed in accordance with the protocol established by the World Health Organization. SARS-CoV-2 nucleic acid testing was performed using RT-PCR assay according to the National Health Commission guidelines for laboratory testing of pneumonia with novel coronavirus infection $[10,11]$.

\section{The COVID-19 patient}

The case is determined by a positive result by real-time reverse-transcriptase-polymerase-chain-reaction (RT-PCR) assay of the SARS-Cov-2 virus in patient's pharyngeal and anal swab specimens. Only the laboratory-confirmed patients were included in the final analysis.

\section{Asymptomatic patient}

An asymptomatic case is defined as someone who shows no clinical symptoms within 14 days before the diagnosis, tests positive for SARS-CoV-2 on RT-PCR or serumspecific IgM antibodies, and is identified through close contact screening, cluster epidemic investigation and traceback investigation.

\section{The exposure}

The exposure is defined as the following situations within 14 days before the onset of illness applicable to individuals: 1) traveling to or living in Wuhan or other regions with severe epidemics abroad; 2) having contact with SARS-CoV-2 infected individuals whose nucleic acid test was positive or with patients who had fever or respiratory symptoms coming from Wuhan or other regions abroad that have been severely affected by the epidemic; 3) having been to 2 or more cases occurred fever or respiratory symptoms in a small area (such as home, office, school class, workshop, construction site, etc.).

\section{Cluster outbreak}

The cluster outbreak is defined as 2 or more presumptive confirmed cases reported with fever or respiratory symptoms within 14 days after having been in the same confined space (such as home, office, school class, workshop, construction site, etc.), which provides the possibility of interpersonal transmission and being infected due to co-exposure.

\section{Close contact}

Close contact refers to an individual who has not taken effective protection when in proximity of suspected or confirmed cases 2 days before the onset of symptoms or 2 days before the collection of asymptomatic specimens.

\section{Statistical analysis}

We setup the EXCEL databases to include all questionnaires, clinic and laboratory data of two family COVID19 patients. The continuous variables were shown as medians and interquartile ranges (Q1-Q4), Median (IQR), or medians and ranges, Median (min-max). The categorical variables were summarized as counts and percentages, no. (\%). All the figures were drawn using Graphad Prism 8 software, and all the analyses were performed using SPSS software (Statistical Package for the Social Sciences, version 26.0).

\section{Results}

\section{Characteristics of two family cluster cases}

In the cross-sectional study of COVID-19 in Guangzhou, we found that there were two notable family cluster cases, which included 3 (family No.1: patient A, B and C) and 2 (family No.2: patient D and E) cases of COVID-19 patients, respectively. As listed in Table 1, patient A was male and 70 years old; patient $B$ and $C$ were female and were 68 and 38 years old. Patient D was a 64 year old female, and patient $\mathrm{E}$ was male and 66 years of age. All patients had fever at onset, except for patient E, who was symptomless.

\section{Information of family No.1}

Patient A, 70 years old, developed a fever at $38^{\circ} \mathrm{C}$ accompanied with runny nose on January 19th, 2020, as shown in Fig. 1. Patient B, patient A's wife, developed a fever at $37.5^{\circ} \mathrm{C}$ with an occasional dry cough on January 23th. Patient $\mathrm{C}$, their daughter, developed a fever at $38.5^{\circ} \mathrm{C}$ without other symptoms on January 19 th. On January 24th, the three patients visited Jinshazhou Hospital of Guangzhou Chinese Medicine University for treatment. The chest $\mathrm{CT}$ of patient A showed bilateral lung inflammation and emphysema and blood test showed decreased lymphocyte count. The chest CT result of patient $C$ also showed bilateral lung inflammation, while that of patient $B$ was normal. On the night of the same day, they were admitted to the isolation ward of hospital as suspected cases of COVID-19. At 9:00 a.m. on January 25, their throat swabs were collected by Guangzhou CDC and tested for SARS-CoV-2 virus nucleic acid test, all of which were reported to be positive on the same day, so they were immediately transported by ambulance to the designated COVID-19 hospital for isolation treatment. These three patients were in mild severity. After isolation and treatment in the designated hospital, they were cured and discharged. A total of 18 individuals were identified as close contacts of this family by Guangzhou CDC and so far, all of them were healthy without any symptoms and thus are all relieved of medical observation. 
Table 1 The basic information of 5 patients with COVID-19

\begin{tabular}{|c|c|c|c|c|c|c|c|c|c|c|c|}
\hline Patients & Occupation & Symptoms & Temperature & $\begin{array}{l}\text { Blood } \\
\text { leukocyte } \\
\text { count } \\
\left({ }^{*} 10^{9} / \mathrm{L}\right)\end{array}$ & $\begin{array}{l}\text { Lymphocyte } \\
\text { count }\left({ }^{*} 10^{9} /\right. \\
\text { L) }\end{array}$ & $\begin{array}{l}\text { Lymphocyte } \\
\text { percentage(\%) }\end{array}$ & $\begin{array}{l}\text { Neutrophil } \\
\text { percentage(\%) }\end{array}$ & $\mathrm{CT}$ & Onset date & $\begin{array}{l}\text { Admission } \\
\text { date }\end{array}$ & $\begin{array}{l}\text { Out } \\
\text { date }\end{array}$ \\
\hline $\begin{array}{l}\text { Patient } \\
\text { A }\end{array}$ & Retiree & $\begin{array}{l}\text { Fever, } \\
\text { running } \\
\text { nose }\end{array}$ & $38^{\circ} \mathrm{C}$ & 4.25 & 0.74 & 17.4 & 75.1 & $B+$ & $\operatorname{Jan} 132020$ & $\begin{array}{l}\mathrm{Jan} 24 \\
2020\end{array}$ & $\begin{array}{l}\text { Feb13 } \\
2020\end{array}$ \\
\hline $\begin{array}{l}\text { Patient } \\
\text { B }\end{array}$ & Retiree & $\begin{array}{l}\text { Fever, dry } \\
\text { cough }\end{array}$ & $37.5^{\circ} \mathrm{C}$ & 6.05 & 2.1 & 34.7 & 56.8 & $B-$ & $\operatorname{Jan} 232020$ & $\begin{array}{l}\operatorname{Jan} 24 \\
2020\end{array}$ & $\begin{array}{l}\text { Feb23 } \\
2020\end{array}$ \\
\hline $\begin{array}{l}\text { Patient } \\
C\end{array}$ & $\begin{array}{l}\text { Civil } \\
\text { servants }\end{array}$ & Fever & $38.5^{\circ} \mathrm{C}$ & 5.66 & 1.47 & 26.04 & 65.4 & $B+$ & Jan19 2020 & $\begin{array}{l}\operatorname{Jan} 24 \\
2020\end{array}$ & $\begin{array}{l}\text { Feb8 } \\
2020\end{array}$ \\
\hline $\begin{array}{l}\text { Patient } \\
\text { D }\end{array}$ & Retiree & Fever & $37.8^{\circ} \mathrm{C}$ & 5.42 & 1.21 & 22.34 & 66.44 & $B+$ & Jan21 2020 & $\begin{array}{l}\operatorname{Jan} 27 \\
2020\end{array}$ & $\begin{array}{l}\text { Feb21 } \\
2020\end{array}$ \\
\hline $\begin{array}{l}\text { Patient } \\
\text { E }\end{array}$ & Retiree & - & Normal & Normal & Normal & Normal & Normal & $\begin{array}{l}\text { R } \\
\text { up } \\
+\end{array}$ & asymptomatic & $\begin{array}{l}\operatorname{Jan} 27 \\
2020\end{array}$ & $\begin{array}{l}\text { Feb21 } \\
2020\end{array}$ \\
\hline
\end{tabular}

Note: Age (range, 38-70 years); CT Computerized tomography, B Bilateral lung, $R$ up the upper lobe of the right lung

\section{Information of family No.2}

As described in Fig. 2, Patient D, a 64-year-old woman, experienced the onset of fever at $37.8^{\circ} \mathrm{C}$ without other symptoms on January 21th, and went to Jinsha Street Community Health Service Center for treatment on January 22th. Patient E, patient D's husband, without any respiratory symptoms, he went to Jinshazhou Hospital of Guangzhou Chinese Medicine University with his wife on January 27th. The chest CT test of patient D showed bilateral lung inflammation and that of patient $E$ showed inflammation in the upper lobe of the right lung. Both patients were admitted to the isolation ward of hospital as suspected cases of COVID-19 on the same day. On January 28th, the outcomes of virus nucleic acid test were both positive of SARS-CoV-2 so that they were transported by ambulance to the designated hospital of COVID-19 for isolation treatment on January 29th. They were both mild patients in stable condition. After isolation and treatment in the designated hospital, they were cured and discharged. Three other individuals were identified as close contacts of this family by Guangzhou CDC and so far, all were in good health without any symptoms so that they were all relieved of medical observation.

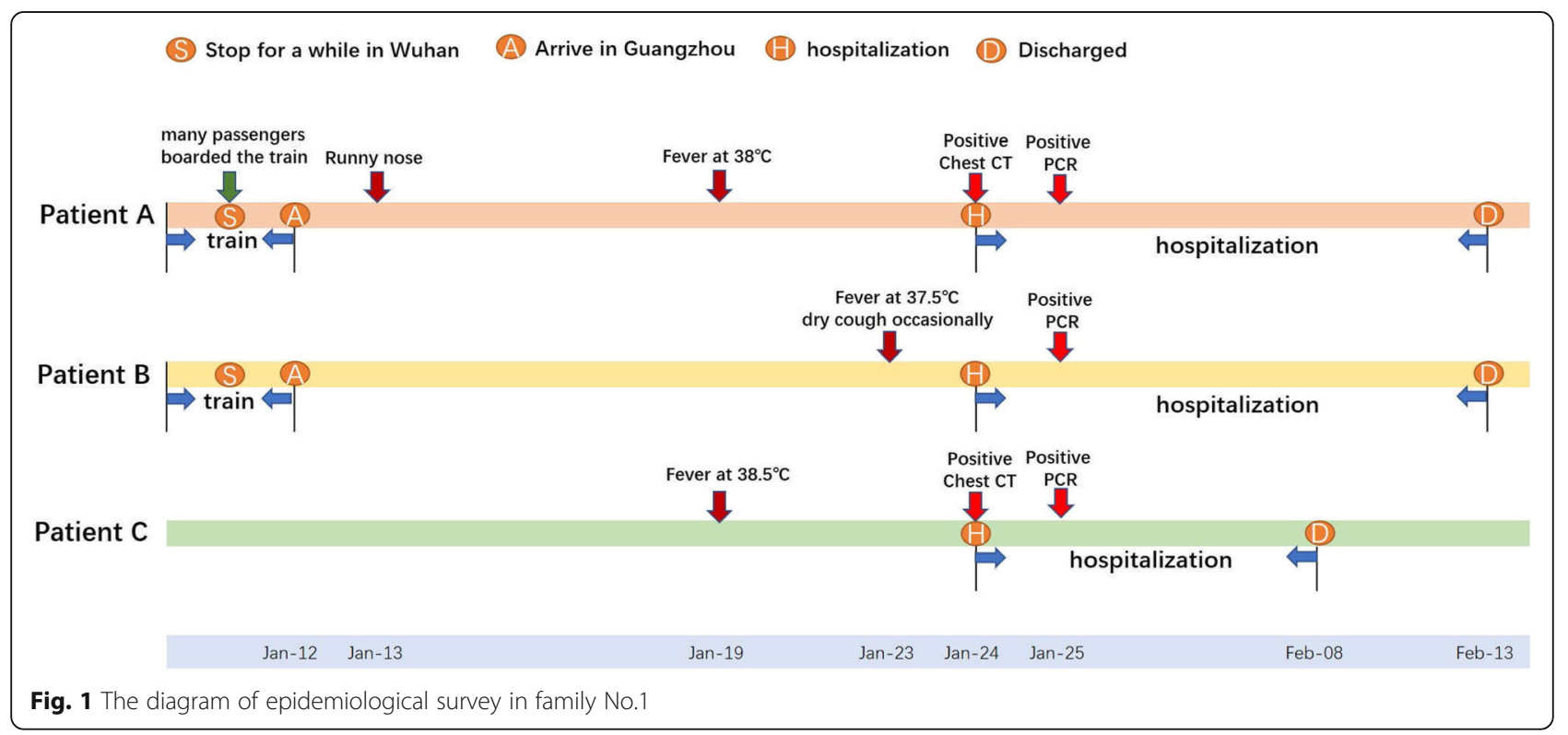




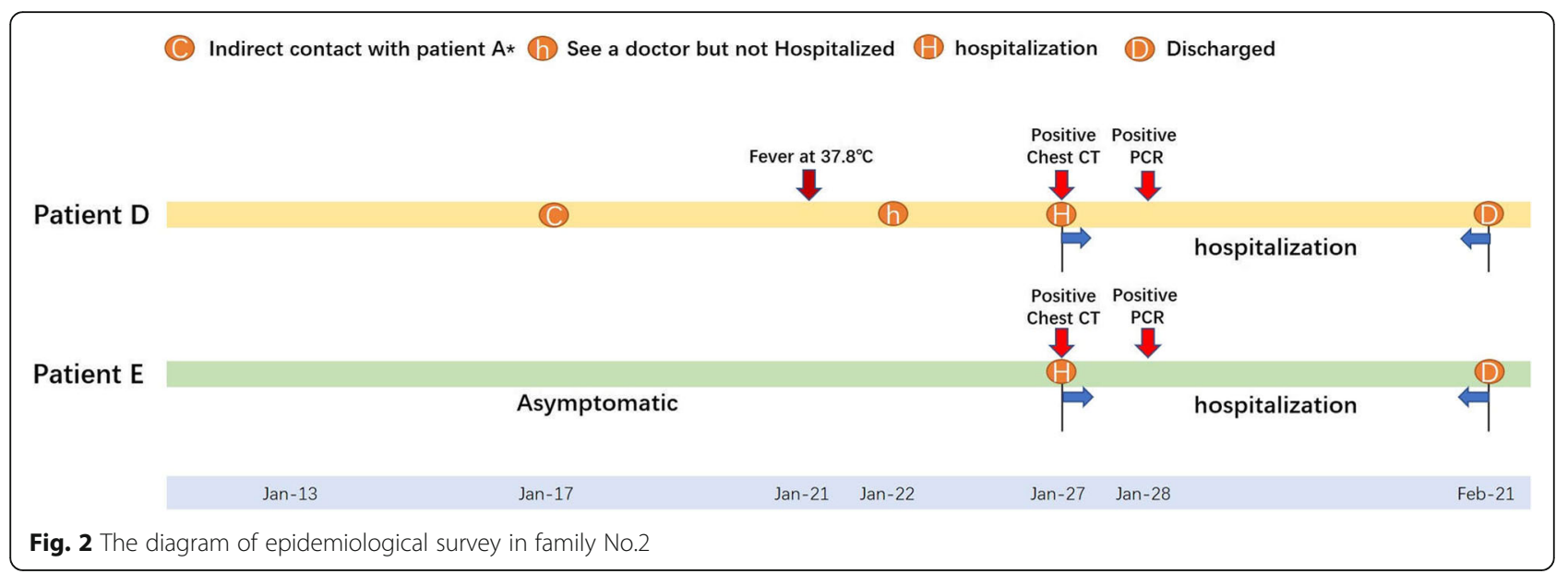

\section{The results of viral nucleic acid test}

As presented in Figs. 3, 5 patients from the above two families were positive of SARS-CoV-2, while the test results of throat swabs and blood samples collected from relevant individuals were all negative, as listed in Table $\mathrm{S}$ 1 and $S$ 2. Of all environmental samples, only the door handle of family No.1 tested positive of SARS-CoV2(shown in Fig. 4), and the rest were negative that listed in Table 2.

\section{Epidemiological investigation}

All three members of family No.1 said that they had no contact with COVID-19 patients nor individuals from
Hubei province. However, patient A and patient B had traveled to Guangzhou by train from other province to visit their children (patient $\mathrm{C}$ ). The train stopped in $\mathrm{Wu}$ han for several minutes. That stop was a crowded and compact hub where many passengers boarded the train. Therefore, as shown in Fig. 5, it was inferred that patient $\mathrm{A}$ and patient $\mathrm{B}$ were infected through close contact to passengers who might be unknown patients of COVID19. Later they passed on the COVID-19 to their daughter (patient C) as close family contact. Both members of family No.2 said that they had no contact with the patients in family No.1 or individuals from Hubei province, and had no link to Wuhan city.

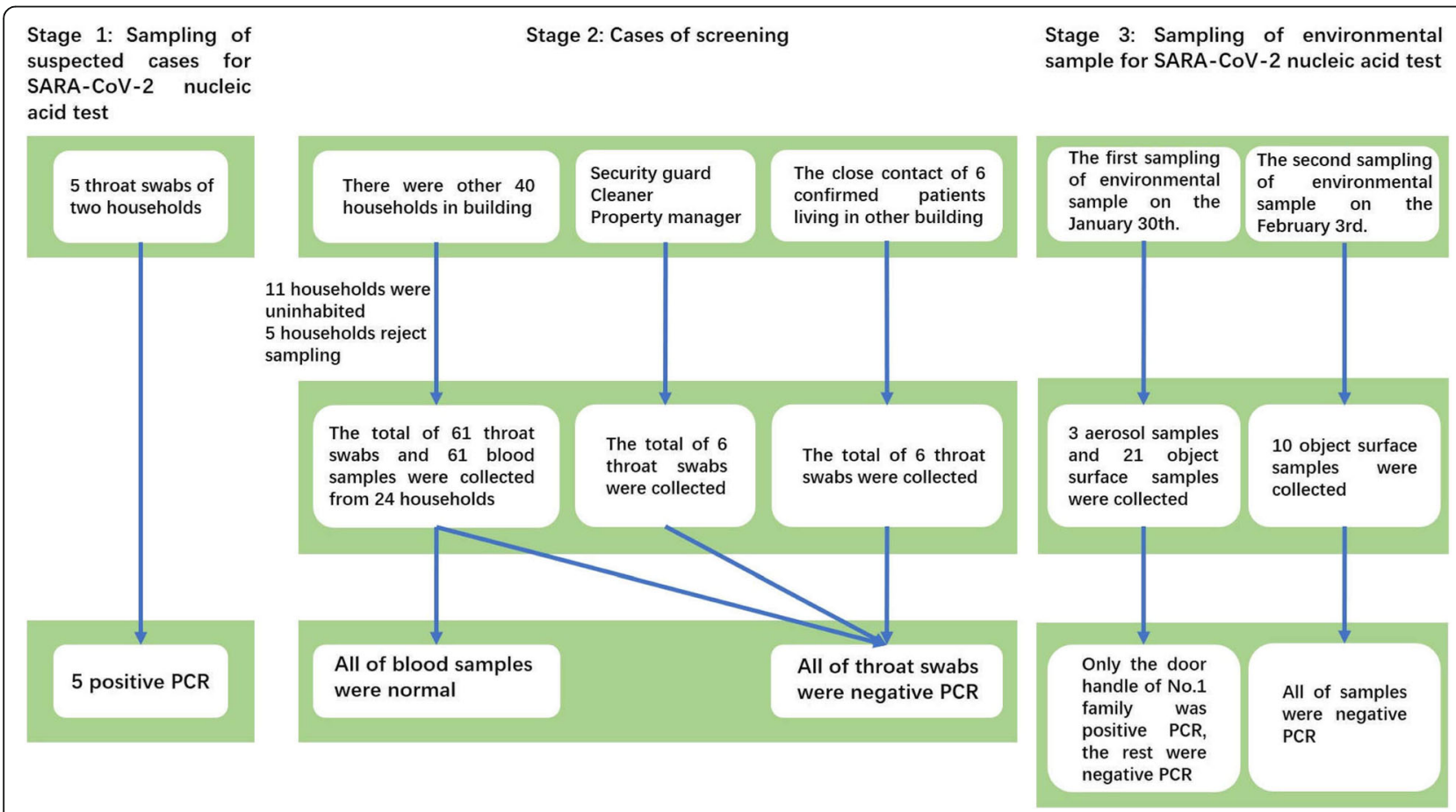

Fig. 3 The graphical of detecting steps of SARS-CoV-2 among the patients and their close contacts, and their surroundings 


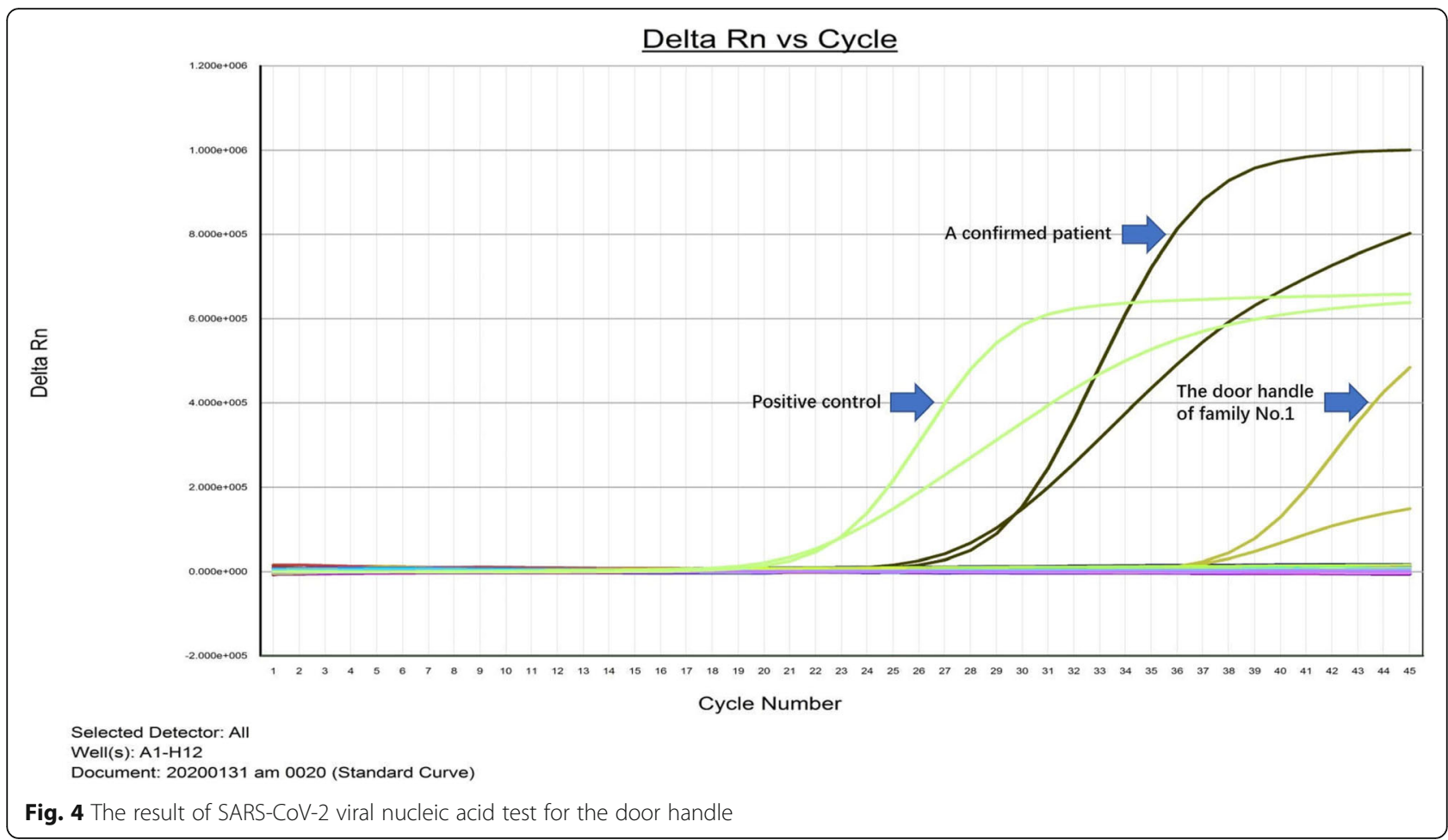

\section{Epidemiological relationship between family No.1 and family No.2}

According to the traceability investigation through applying the big data tools, we found that patient $\mathrm{A}$ had a bad habit in personal hygiene that he often blew nose using his own hand, which was what he again did before touching the button of closing door in elevator. As shown in Fig. 5, on January 17th, patient A blew nose using his own hand before touching the button of closing door in elevator, then 2 min after patient $\mathrm{A}$ got out of the elevator, patient $\mathrm{D}$ entered the same elevator and touched the same button. The most important thing is that patient $\mathrm{D}$ immediately flossed with a toothpick after touching the elevator button. Therefore, it was speculated that patient D (family No.2) was infected for COVID-19 by means of snot-oral indirect transmission of touching the button of elevator contaminated by snot with virus from patient A (family No.1).

\section{Discussion}

Although the epidemic of COVID-19 has been going on for months, the epidemiological characteristics of the SARS-CoV-2 virus are not yet fully understood. With the import of COVID-19 cases, there were many new local patients in the cities outside of Hubei province [5, 12]. Some cities have a high proportion of clustering cases, such as Beijing, where, as of February 11, a total of 77 clustered cases involving 251 patients accounted for $71 \%$ of a total of 352 patients [13]. A point worth noting about this epidemic is that some local cases have no clear source of infection in the cities outside of Hubei province.

Recently, there were several reports that the new coronavirus could spread via droplets, contact and natural aerosols from human-to-human $[1,4,14,15]$, causing a high possibility of a pandemic. As more and more new cases with COVID-19 are reported worldwide [16, 17], it seems to be a gloomy reality. To contain the spread of the COVID-19 epidemic without delay, a deeper understanding of the SARS-CoV-2 virus should be presented [18]. To reduce the impact and spread of the disease, it is essential to limit human-to-human transmission to reduce secondary infections among close contacts and health care workers.

As reported in this study, we found two family clusters infected with SARS-CoV-2 in the same building in Guangzhou, China. Through testing the external environment samples, we found that the sample taken from door handle of family No.1 tested positive of SARS$\mathrm{CoV}-2$, which indicated that contaminants with virus from confirmed patients can pollute the environment of public places. Furthermore, the patient D of family No.2 was infected via the snot-oral indirect transmission, indicating that SARS-CoV-2 virus can survive in the environment for at least a short period of time. As previously reported by Zou LR et al., higher viral loads were detected soon after symptom onset, with higher viral loads detected in the nose than in the throat $[19,20]$, which 
Table 2 The outcome of environmental samples tested

\begin{tabular}{|c|c|c|c|}
\hline Sample number & Sampling area & Sample type & Outcomes \\
\hline \multicolumn{4}{|c|}{ The first sampling of environmental samples on the 30 January, 2020.} \\
\hline 1 & Up and down Button of 01 floor outside of elevator & Object surface swab & Negative \\
\hline 2 & Button of close and open inside of elevator & Object surface swab & Negative \\
\hline 3 & Button of 01-B1 floor inside of elevator & Object surface swab & Negative \\
\hline 4 & Button of 02-11 floor inside of elevator & Object surface swab & Negative \\
\hline 5 & The ground of elevator & Object surface swab & Negative \\
\hline 6 & The wall of elevator & Object surface swab & Negative \\
\hline 7 & Both sides of elevator door & Object surface swab & Negative \\
\hline 8 & The door of elevator & Object surface swab & Negative \\
\hline 9 & Button of 10 floor & Object surface swab & Negative \\
\hline 10 & The door handle of No.1 family & Object surface swab & Positive* \\
\hline 11 & Button of 11 floor & Object surface swab & Negative \\
\hline 12 & The door handle of No.2 family & Object surface swab & Negative \\
\hline 13 & The door handle of the big door of building & Object surface swab & Negative \\
\hline 14 & Button of 02 floor outside of elevator & Object surface swab & Negative \\
\hline 15 & Button of 03 floor outside of elevator & Object surface swab & Negative \\
\hline 16 & Button of 04 floor outside of elevator & Object surface swab & Negative \\
\hline 17 & Button of 05 floor outside of elevator & Object surface swab & Negative \\
\hline 18 & Button of 06 floor outside of elevator & Object surface swab & Negative \\
\hline 19 & Button of 07 floor outside of elevator & Object surface swab & Negative \\
\hline 20 & Button of 08 floor outside of elevator & Object surface swab & Negative \\
\hline 21 & Button of 09 floor outside of elevator & Object surface swab & Negative \\
\hline 22 & Inside the elevator & aerosol & Negative \\
\hline 23 & The house of No.1 family & aerosol & Negative \\
\hline 24 & The house of No.2 family & aerosol & Negative \\
\hline \multicolumn{4}{|c|}{ The second sampling of environmental samples on the 3 February, 2020.} \\
\hline 1 & Button inside of elevator & Object surface swab & Negative \\
\hline 2 & Button of 08 floor outside of elevator & Object surface swab & Negative \\
\hline 3 & First floor stair railing & Object surface swab & Negative \\
\hline 4 & The door handle of No.2 family & Object surface swab & Negative \\
\hline 5 & Third floor stair railing & Object surface swab & Negative \\
\hline 6 & First floor stair railing outside of big door of building & Object surface swab & Negative \\
\hline 7 & The door handle of 702 household & Object surface swab & Negative \\
\hline 8 & The door handle of 1102 household & Object surface swab & Negative \\
\hline 9 & The door handle of No.1 family & Object surface swab & Negative \\
\hline 10 & Button of 02 floor outside of elevator & Object surface swab & Negative \\
\hline
\end{tabular}

further demonstrated that indirect contact transmission by means of snot-oral Transmission might be an effective way to spread the epidemic disease. For the surface survival of virus, SARS-CoV-2 can remain viable and infectious on surfaces up to days, so common surface transmission of the virus is highly possible [21]. Although the elevator buttons were detected as negative for viral nucleic acid, the possible reason is that the buttons have been used many times and the time interval from contamination to sampling is too long. During this period, the interior of the elevator has been disinfected several times. With the return to work and the gradual opening of public places, the migration of large population is a huge challenge for prevention and control of the epidemic. Therefore, it is also still important for the prevention and control of the epidemic to pay attention to personal hygiene, taking measures such as wearing a facemask, washing hands frequently and not touching 


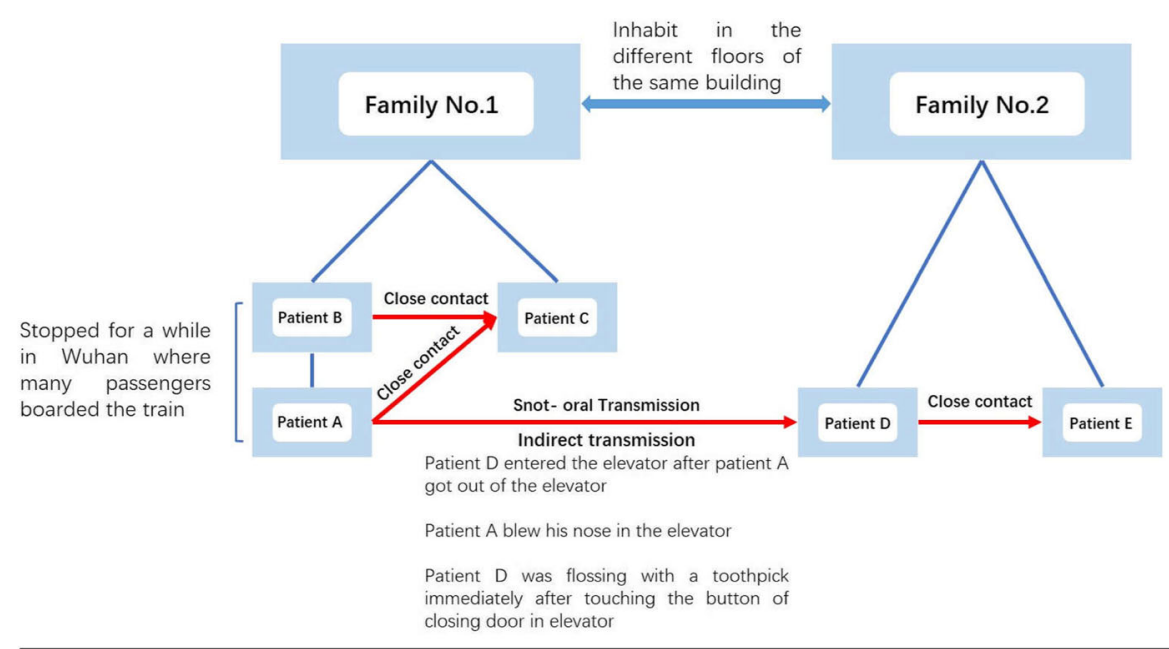

(G) Patient A got out of the elevator

(E) Patient $D$ entered the elevator

No one else entered or

got out of the elevator

during this period

Jan-17

Two minutes

IE

Fig. 5 The epidemiological investigation and their relationship between family No.1 and family No.2

nose and mouth before washing hands and so on, as well as disinfection of public places in the coming time period.

Our study had some obvious limitations. First, on January 17, no samples were collected on the day of the elevator button pollution and our elevator button sampling took place on January 30. Second, according to the weak positive test of patient A's home handle and his poor hygiene habits, it is our inference that the infection of patient $\mathrm{D}$ was caused by the transmission of the elevator button polluted by patient A's nose. Third, we cannot exclude the possibility of transmission of the virus by unknown infected persons, such as asymptomatic carriers [22].

\section{Conclusions}

In summary, this study provides direct evidence substantiating that SARS-CoV-2 can infect other individuals by means of snot-oral transmission as one mode of indirect contact transmission. This finding is of significance for the prevention and control of COVID-19 and the formulation of the public health policies and measures. Based on previous reports and the evidence provided in this study, it is important to pay attention to personal hygiene and disinfection in public places.

\section{Supplementary information}

Supplementary information accompanies this paper at https://doi.org/10 1186/s12889-020-09296-y.

Additional file 1: Table S1. The outcome of whole blood samples tested. Table S2. The outcome of throat swabs tested.

\section{Abbreviations}

SARS-CoV-2: Severe acute respiratory syndrome coronavirus 2; COVID-19: Corona virus disease 2019; RT-PCR: Real-time reverse transcriptase polymerase chain reaction; IQR: Interquartile ranges; CT: Computerized tomography; B: Bilateral lung; $R_{u p}$ : Upper lobe of the right lung

\section{Acknowledgements}

We thank Bogi Rao, Yingyi Feng, Yujie Pan, Zhi Li, Chun Mao, Wenhui Lun, Zeqin Huang, and Junyi Ye from Guangzhou Medical University (Guangzhou, China) for assisting with data collection. We thank Bogi Rao for his assistance in preparing the figures. We thank Fuman Qiu from Guangzhou Medical University (Guangzhou, China) for his assistance in writing the manuscript. We are very grateful to all staff at Guangzhou Center for Disease Control and Prevention for providing the data and all medical staff members and field workers who are working on the frontline of caring for patients and collecting the data.

\section{Authors' contributions}

$\mathrm{HZ}, \mathrm{LZ}$ and $\mathrm{JL}$ designed the study. CX, KL, ZZ, HP, DW, JC and XZ collated the data. $\mathrm{HZ}$ analyzed epidemiologic data. $\mathrm{HZ}, \mathrm{CX}, \mathrm{YG}$ and $J Y$ contributed to interpreting the results. $\mathrm{HZ}$ wrote the manuscript. $\mathrm{XL}, \mathrm{J}$ and $\mathrm{LZ}$ revised the manuscript. All authors read and approved the final manuscript.

\section{Funding}

This study was supported by the National Natural Science Foundation of China. 
81872694, 81673267 and 81473040 (J. Lu); Local Innovative and Research Teams Project of Guangdong Pearl River Talents Program 2017BT01S155 (J Lu); Health Industry Scientific Research Project of Gansu Province GSWS KY2018-18(H Zhao). The funders had no role in study design, data collection and analysis, decision to publish, or preparation of the manuscript.

\section{Availability of data and materials}

The datasets used and/or analyzed during the current study are available from the corresponding author on reasonable request.

\section{Ethics approval and consent to participate}

This study was approved by the Ethical Committee of Guangzhou Center for Disease Control and Prevention (No. GZCDC20200311). Because of the urgent need to collect data on this emerging infectious disease, the requirement for written informed consent was waived. The oral informed consent was obtained from each participant and this form of consent was confirmed by the Ethical Committee.

\section{Consent for publication}

Not applicable.

\section{Competing interests}

The authors declare no competing interests.

\section{Author details}

${ }^{1}$ The Institute for Public Health, Guangzhou Medical University, 195 Dongfengxi Road, Guangzhou 510182, PR China. ${ }^{2}$ Guangzhou Center for Disease Control and Prevention, 1Qide Road, Guangzhou 510440, PR China. ${ }^{3}$ State Key Lab of Respiratory Disease, The First Affiliated Hospital, Guangzhou Medical University, 195 Dongfengxi Road, Guangzhou 510182, PR China. ${ }^{4}$ Department of English and American Studies, Faculty of Languages and Literatures, Ludwig Maximilian University (LMU), Munich, Germany. ${ }^{5}$ Baiyun District Center for Disease Control and Prevention, Guangzhou, PR China.

Received: 14 March 2020 Accepted: 26 July 2020

Published online: 05 August 2020

\section{References}

1. Li Q, Guan X, Wu P, Wang X, Zhou L, Tong Y, et al. Early transmission dynamics in Wuhan, China, of novel coronavirus-infected pneumonia. N Engl J Med. 2020;382(13):1199-207. https://doi.org/10.1056/NEJMoa2001316.

2. Wang C, Horby PW, Hayden FG, Gao GF. A novel coronavirus outbreak of global health concern. Lancet. 2020;395(10223):470-3. https://doi.org/10. 1016/S0140-6736(20)30185-9.

3. Du Z, Wang L, Cauchemez S, Xu X, Wang X, Cowling BJ, Meyers LA. Risk for transportation of coronavirus disease from Wuhan to other cities in China. Emerg Infect Dis. 2020;26(5):1049-52. https://doi.org/10.3201/eid2605. 200146.

4. Deng SQ, Peng HJ. Characteristics of and public health responses to the coronavirus disease 2019 outbreak in China. J Clin Med. 2020;9(2):575. https://doi.org/10.3390/jcm9020575.

5. Tong ZD, Tang A, Li KF, Li P, Wang HL, Yi JP, Zhang YL, Yan JB. Potential Presymptomatic transmission of SARS-CoV-2, Zhejiang Province, China, 2020. Emerg Infect Dis. 2020;26(5):1052-4. https://doi.org/10.3201/eid2605. 200198

6. Phan LT, Nguyen TV, Luong QC, Nguyen TV, Nguyen HT, Le HQ, et al. Importation and human-to-human transmission of a novel coronavirus in Vietnam. N Engl J Med. 2020;382(9):872-4. https://doi.org/10.1056/ NEJMc2001272.

7. Chan JF, Yuan S, Kok KH, To KK, Chu H, Yang J, et al. A familial cluster of pneumonia associated with the 2019 novel coronavirus indicating personto-person transmission: a study of a family cluster. Lancet. 2020;395(10223): 514-23. https://doi.org/10.1016/S0140-6736(20)30154-9.

8. CCTV news, http://news.cctv.com/. [cited 2020 Feb 22].

9. National Health Commission of the People's Republic of China. http:// wwwnhcgovcn. [cited 2020 Feb 23].

10. Huang C, Wang Y, Li X, Ren L, Zhao J, Hu Y, et al. Clinical features of patients infected with 2019 novel coronavirus in Wuhan, China. Lancet. 2020;395(10223):497-506. https://doi.org/10.1016/S0140-6736(20)30183-5.
11. World Health Organization. Clinical management of severe acute respiratory infection when novel coronavirus (2019-nCoV) infection is suspected: interim guidance. https://www.who.int/docs/default-source/coronaviruse/dinicalmanagement-of-novel-cov.pdf. opens in new tab. [cited 2020 Jan 28].

12. Wu J, Liu J, Zhao X, Liu C, Wang W, Wang D, et al. Clinical Characteristics of Imported Cases of COVID-19 in Jiangsu Province: A Multicenter Descriptive Study. Clin Infect Dis. 2020:ciaa199. https://doi.org/10.1093/cid/ciaa199.

13. Beijing city health commission, http://wjw.beijing.gov.cn/. [cited 2020 Feb 11].

14. Wang D, Hu B, Hu C, Zhu F, Liu X, Zhang J, et al. Clinical characteristics of 138 hospitalized patients with 2019 novel coronavirus-infected pneumonia in Wuhan, China. JAMA. 2020;323(11):1061-9. https://doi.org/10.1001/jama. 2020.1585.

15. Chang D, Lin M, Wei L, Xie L, Zhu G, Dela Cruz CS, Sharma L. Epidemiologic and clinical characteristics of novel coronavirus infections involving 13 patients outside Wuhan, China. JAMA. 2020;323(11):1092-3. https://doi.org/ 10.1001/jama.2020.1623.

16. Kim JY, Ko JH, Kim Y, Kim YJ, Kim JM, Chung YS, et al. Viral load kinetics of SARS-CoV-2 infection in first two patients in Korea. J Korean Med Sci. 2020; 35(7):e86. https://doi.org/10.3346/jkms.2020.35.e86.

17. Anzai A, Kobayashi T, Linton NM, Kinoshita R, Hayashi K, Suzuki A, et al. Assessing the impact of reduced travel on exportation dynamics of novel coronavirus infection (COVID-19). J Clin Med. 2020;9(2):601. https://doi.org/ 10.3390/jcm9020601

18. Sun P, Lu X, Xu C, Sun W, Pan B. Understanding of COVID-19 based on current evidence. J Med Virol. 2020;92(6):548-51. https://doi.org/10.1002/ jmv. 25722.

19. Zou L, Ruan F, Huang M, Liang L, Huang H, Hong Z, et al. SARS-CoV-2 viral load in upper respiratory specimens of infected patients. N Engl J Med. 2020;382(12):1177-9. https://doi.org/10.1056/NEJMc2001737.

20. Xie C, Lu J, Wu D, Zhang L, Zhao H, Rao B, Yang Z. False negative rate of COVID-19 is eliminated by using nasal swab test. Travel Med Infect Dis. 2020;101668. https://doi.org/10.1016/j.tmaid.2020.101668.

21. Neeltje D, Trenton B, Dylan H. Aerosol and surface stability of SARS-CoV-2 as compared with SARS-CoV-1. N Engl J Med. 2020;382(16):1564-7. https://doi. org/10.1056/NEJMc2004973.

22. Zhao H, Lu X, Deng Y, Tang Y, Lu J. COVID-19: asymptomatic carrier transmission is an underestimated problem. Epidemiol Infect. 2020;148:E116. https://doi.org/10.1017/S0950268820001235.

\section{Publisher's Note}

Springer Nature remains neutral with regard to jurisdictional claims in published maps and institutional affiliations.

\section{Ready to submit your research? Choose BMC and benefit from:}

- fast, convenient online submission

- thorough peer review by experienced researchers in your field

- rapid publication on acceptance

- support for research data, including large and complex data types

- gold Open Access which fosters wider collaboration and increased citations

- maximum visibility for your research: over $100 \mathrm{M}$ website views per year

At $\mathrm{BMC}$, research is always in progress.

Learn more biomedcentral.com/submissions 